\title{
Working Youth and Education in Postwar Greece: Night Schools as Arenas of Political Struggle and Cultural Practices
}

\author{
Dimitra Lampropoulou ${ }^{1}$ \\ University of Athens
}

\begin{abstract}
The Working Pupils' Association of High Schools was founded in 1960s' Greece as an organization of working boys and girls who attended secondary evening schools after having finished their daily waged work. Acting simultaneously as a conventional union and as a collective that encouraged artistic activity, the association elaborated new meanings about the relation between work, education, and youth. The postwar period saw the rapid expansion of secondary schooling to the lower classes, which affected deeply both youth and the working class. However, significant attention has not yet been paid to pupils generally, let alone to those of the working class. Addressing this lacuna, this article suggests a new perspective on the relation between the histories of youth, class, political acculturation, and social change in the second half of the twentieth century.
\end{abstract}

Modern political struggles have for a very long time given prominence to education as a condition for people and collectivities to participate in the public sphere. ${ }^{2}$ Since the nineteenth century, literacy and educational institutions and practices were a context of political action not only for the middle classes, but for working-class movements as well. It goes without saying that this context has always been historically dependent: Workers' connection to education has relied on time conjunctures, cultural environments, gender and age relations, local backgrounds, and political horizons. In what follows, I will examine the case of a school-based young workers' organization, the Working Pupils' Association of High Schools [Syllogos Ergazomenvn Mathiton Mesis Ekpedefsis, hereafter SEMME], ${ }^{3}$ which was created in Greece in the early 1960s. Scholarship about youth in postwar Europe has not yet paid significant attention to pupils generally, let alone to those in the working class. Still, that period saw the rapid expansion of secondary schooling to the lower classes, which affected deeply both youth and the working class. Addressing this lacuna can offer new perspectives on the relation between the histories of youth, class, political acculturation, and social change in the second half of the twentieth century.

In Greece, the phrase "working pupils" referred to adolescents and young men and women who attended secondary evening schools after having finished their working day. I am proposing that, in the postwar social context, night schooling was conceived by SEMME as a space where the hierarchical stratification of Greek society was not only experienced but could also be contested. 
The access to continuing education at a young age ruptured the predetermined social position of a large group of adolescent boys and girls, whose labor was usually undervalued and whose social status was traditionally marginal and looked down upon. There was no better proof of this situation than the cultural activities of the association, which are today remembered by the men and women who participated in them in their youth as among the most important features of their SEMME membership. Their memories help us understand how meanings of political participation are historically produced and in what ways fundamental notions of postwar political identities, such as "youth," "learning," and "collectivity" are structured both personally and collectively. Using as a point of departure two personal accounts, I will first outline the major features of postwar educational framework and present the key aspects of the SEMME's aims and activities. Second, I will focus on how today's adults remember the ways in which they learned to negotiate their private/ public, personal/political relationships as politically active youth members of SEMME. Before I do so, however, I will survey some central points of Greek history in the 1950 s and 1960 s to make clearer the main parts of the story. ${ }^{4}$

Between 1940 and 1950 Greece experienced two devastating wars in succession. The military occupation by the Axis powers was followed by a civil war (1946-1949) between communists and other left-wing forces and a united front of Rightists, monarchists, and the national army, aided decisively by US officials and experts. The Right emerged victorious from the military and political conflict, the monarchy was restored, and Greece gained its indisputable position in NATO and the West. But behind the façade of parliamentary democracy stood an authoritarian core..$^{5}$ A set of acts and decrees known as the Parasyntagma [Paraconstitution] institutionalized a number of emergency provisions, such as banning the Communist Party of Greece as well as other political organizations related to the communists and the Resistance movement, deportation orders, certificates of good citizenship, deprivation of nationality, purging of civil servants, and so forth - all of which penalized and constrained the Left.

At first Greece clearly benefited from the accommodation, as the economy boomed. Between 1964 and 1975 the GNP and the gross manufacturing product of the country grew at an annual average rate of 6.5 and 10.2 percent, respectively. Average annual income per capita rose from \$157 in 1951 to \$1,071 in 1972 . But prosperity was uneven, and social inequalities persisted despite economic growth. Wages and salaries were quite low and agriculture remained the least profitable area of the economy. In the trade sector, Greece imported far more than it exported. Industry depended on foreign investment and imported technology. Official economic development policies relied heavily on a form of crony capitalism coupled with the maintenance of industrial peace and low wages through government-dependent syndicates, overt police control of oppositional trade unions, and state intervention in industrial disputes.

Nevertheless, Greek society witnessed some major changes during the 1950s and 1960s. A network of roads connected theretofore isolated parts of the countryside with the urban centers. Emigration either from the countryside 
to the cities, especially Athens, or abroad-northern Europe, Canada, Australia - reached unprecedentedly high levels, and unparalleled rates of urbanization produced new ways of life. A key element of those new ways of life was the massive presence of adolescents and young people in urban cultural projects, political activities, and educational institutions.

It is important to consider at this point the significance of public youth activities and discourses about youth in the decades that succeeded the end of the Second World War. ${ }^{6}$ In both the European and American continents, the hope that the younger generation would bring an end to the cycle of war and crisis, which had marked the first half of the century, kept pace with concerns that young people would be lost morally or move in politically wrong directions. In the second half of the twentieth century young people's autonomy and action, whether through political protest or through cultural expression, were the most visible features of their dynamic entry into "publicness." In any case, the category "youth" was now recognized by both government officials and the most subversive young peoples' organizations as an important feature of the increasingly tense social, cultural, and political conjuncture that characterized the era.

Greece was no exception to this common tendency, although, at least until the fall of the junta in 1974, official practices and ideologies having to do with the positioning of young people in family, education, politics, and law, ranged from conservatism to blunt repression. But while the explosion of politically and culturally radical expressions of youth would not take place in Greece until the mid-1970s, social movements and major cultural projects of the 1960s were nonetheless predominantly youthful. The public presence of youth was evident from the mid-1950s, both in the anticolonial mobilization on the Cypriot question and the spectacular result of the United Democratic Left [Eniea Dimokratiki Aristera, hereafter EDA] in the 1958 general elections. ${ }^{7}$ Despite the leftist defeat in the civil war and although Greek political life was dominated by conservative forces, it had by then become obvious that neither the Left nor various forms of political dissent would be erased from the country's social map.

The story of Greek working pupils' collective action in the sixties came into being at the point where experiences of social inequality, political unrest, youth activity, and hopes of social mobility crossed one another. We will start following this story by looking closely at two individual lives.

\section{The Stories of George and Mary: Experiences of Night Schooling and Political Activism}

George and Mary were night pupils in 1960s' Athens, the capital of Greece. They had both been born in the countryside but followed earlier migrants from their families to the capital city in the hope of bettering their lives. They were about fourteen years old when they had to abandon day high school so that they could get a job. Once they finished their working day, early in the afternoon, they attended the public Ninth Evening High School of Athens. There, 
Mary and George became acquainted with and participated in SEMME, which was for both of them the beginning of a lifelong active involvement in leftist politics. Night school, the working pupils' association, and their urban youth peer group in the 1960s were the focal points around which George and Mary narrated their lives. The following brief account is based on their interviews. ${ }^{8}$

George was born in 1945 in Kastania, a village on the western part of the Aegean island of Samos. His father was a landless peasant who had actively participated in the Resistance movement, was deported to the concentration camp of Makronisos in 1948, released in 1950, and moved as an internal migrant to Athens to work in the quarries of northwestern Attika. George, the youngest of four children in his family, was left behind with his grandparents to finish the elementary school in Samos. Those years were the happiest of his life because of the absolute freedom he enjoyed. He moved to Athens to join the rest of the family in 1958, and one year later he got a job in a cabinetmaking factory and enrolled in the night school. After having spent three years attending night school, working, and socializing with street urchins downtown - the "Gavroches of Athens," as he describes the boys who worked as peddlers, street vendors of lottery tickets, or errand boys - he experienced a major turnabout in reaction to an anticommunist lecture given by one of the professors at school. "I had nothing to do with politics, but I knew that my father was a leftwinger [...] and, brawler as I was, next day I begun taking Avgi [the newspaper of EDA] at school." This is how he got in touch with left-wing pupils whose influence led George to join the ranks of SEMME and later to become a member of the Youth Organization of EDA. Through his new relationships, he became acquainted with literature, political theory, and Marxist economics and participated in a study group with a circle of friends, which was characterized by "let's say more socialist relationships." George undertook various organizational tasks, which he fulfilled successfully. "From an urchin to become a leader, that was a big change," he says. He never finished high school. Instead, he took classes in a cinema and television school and began working as a journalist and writer, which gradually became his main occupation. During the dictatorship, he was arrested and detained. In the postdictatorship years, he participated in the formation of the New Left political group whose precursor had been the study group of the sixties. George remains a longstanding proponent of the ecological movement.

Mary was born in 1949 in Divri, a village at the mountainous region of western Peloponnese. She was the seventh of twelve siblings. Her parents were peasants who cultivated small plots of land and raised livestock. She describes them as people who had no interest in politics, but were "simple, offering and good with their fellow men [...] both very decent." A few days before Christmas 1960, Mary followed her elder brothers and sisters who had already settled in Athens. She finished elementary school in the capital and, at the same time, she was taking care of the household. She had always liked school: "That was our only joy when we were kids. It was a kind of breath for us in the village. [...] We looked forward to the autumn reopening, so that we 
could be with our friends ... because, to be honest, staying in the house meant lots of heavy tasks." Having been an excellent pupil in the city school as well, she enrolled in a public day high school, which she had to leave at the age of fifteen, in spite of her accomplishments, in order to work at the grocery store of her elder brother. She enrolled in the same night school where her siblings had studied before her and finished three years later, the only girl left in her class, determined to take and pass the exams for university. She entered and finished the Pharmaceutical School at the University of Athens and worked as a pharmacist until her retirement in 2014.

During these years, Mary was active in trade union circles and left-wing politics. In 1973, she participated in the students' insurrection against the dictatorship and was arrested and imprisoned. ${ }^{9}$ She had first become involved in political activism during her school years and her connection to SEMME. It was a decision easy to make, as her elder siblings were already affiliated with the organization both formally and on the basis of informal, friendly relationships. Life within SEMME meant fighting for better schooling. But it also offered an opportunity for rewarding interpersonal relations and a range of high-quality recreational activities. During her interview, Mary showed me a lot of old pictures as she recalled her school years: snapshots of the Association's activities - theatrical performances, tours of the theatrical troupe, parties, demonstrations, excursions - images crowded with young men's and women's faces and bodies, who seemed to share feelings of familiarity.

George and Mary actively participated in SEMME, which is the association that concerns us here. The stories they narrated were at the same time personal and collective: accounts of social relations and bonds, full of friends' and relatives' names, as well as the emotions by which they were bound to them, and very often still are. As memory, narration, and biography connect with one another, the stories of the subjects are woven in different spaces and levels of intersubjective communication: the family, the village, the city, the neighborhood, the school, the working place, the association, the group of friends, the political organization. All these versions of sociality act as a means to narrate the condition of working-class youth and its relation to education in the era of profound social changes that was the 1960s. ${ }^{10}$

Histories like those of George and Mary recount adolescents' and young people's lives and political practices in 1960s' Athens in a rather subdued tone, but they were certainly alert to the challenges of the times in almost every aspect of life. As heroes of their own stories, the narrators go through changes, and one of the contexts that transforms their lives is their youth organization, SEMME. Their working pupils' movement did not culminate in the massive protest strikes, dynamic school occupations, or resolute clashes with the police forces that were typical, or stereotypical, actions of post-1968 student movements. But it did face the prohibitions and persecutions characteristic of the educational system of Greece after the civil war: for example, suspensions from school due to participation in "politically dangerous" activities; a ban on political conversation inside the schools; nationalist instruction, with 
sufficient doses of intimidation from members of the teaching staffs; and denunciations of the supposed dominance and pervasiveness of Communists in youthspecific spaces. ${ }^{11}$

\section{Education, Night Schooling and Working Pupils in Postwar Context}

Historians generally agree not only on the size of the social changes that occurred in the postwar world in general and on the European continent in particular, but also on how deep these changes were inscribed in the collective consciousness. ${ }^{12}$ In the 1960s a younger, more urbanized Europe became aware of the great changes that had taken place after the war and demanded that both policy and law address the evident fact that the welfare state policies of the first postwar decade had not significantly altered the inequalities of wealth and that despite increasing prosperity democracy still seemed to exist in name only. ${ }^{13}$

Education was at the center of public discussions on the economy, democratic politics, postwar planning, and social change. Different and often rival parties considered it as a tool of economic and cultural development, a means for social mobility, and a weapon for political freedom. Against the background of the Cold War and anticolonial revolutions, questions about mass education, literacy, and technological modernization were ideologically charged. The educational level of the population and the educational opportunities offered to disadvantaged social groups turned into problems of global dimension. ${ }^{14}$ As the population explosion, economic growth, and prosperity collided, the chief problem facing European states was not how to feed, clothe, house, and employ the growing number of young people, but how to educate them. ${ }^{15}$

Until the 1950s, most children in Europe did not continue their education beyond primary school, and in many of the poorer, mainly rural areas of the continent, dropout rates were very high even in the compulsory primary grades. Secondary general education was until then a privilege of the middle and upper classes, offered mostly to their male offspring and resulting not only in important educational capital, but also in admission to respectable jobs. Things began to change in the late 1940s when educational reforms were considered by most governments to be part of wider social transformations and raising the population's educational level was treated as a means to improve the nation's economic standing in an increasingly competitive international environment. As hordes of young people entered secondary education, expectations of university access, improved employment, and enjoyment of cultural goods were generated in the populace while rulers felt uneasy about the future, the role, and the infrastructure of education, especially at the higher, postsecondary level. Sensitivity toward the issue of "common people's" schooling was closely linked to a more widespread postwar concern for social justice among the lower classes. Education, once considered a privilege, was now seen as a right, and this had political consequences. ${ }^{16}$

Greek officials watched these trends closely, all the while adjusting them to the country's post-civil-war ideological, social, and economic temperament. The 
government's concern proved largely theoretical and was less focused on developing specific strategies. But within the wider society, with its rising expectations, the desire for education fit perfectly with the European context, particularly from the late 1950s onward. The end of Nazi occupation had left Greece with immediate and urgent educational problems. For at least two decades ahead, illiteracy was a thorny issue in the planning of all postwar administrations. ${ }^{17}$ Even after the fall of the dictatorship and despite the significant changes that were taking place through a new legislative framework enacted between 1976 and 1977, there were still many counted among "those whom reform forgot" (i.e., the populations that the educational system pushed to the margins), including the illiterate and semiliterate, residents of rural and remote regions, ethnic minorities, and women. ${ }^{18}$

In modern Greek history, the "educational question" was an aspect of the broader "social question" and part of the country's modernization problems. Since the first decades of the twentieth century, the dire educational status of the population had attracted the interest of liberal, socialist, and communist intellectuals who stressed the moral and political right of all citizens to education and insisted that the educational system should meet the requirements of economic development. But the reform efforts of the first half of the century were unable to open up educational opportunities to broad segments of the population, primarily because of rigid conservatism, reactionary nationalism, and social elitism, which remained deeply ingrained in the Greek educational system. However, with increasing intensity from the mid-1950s on, the "educational question" became a key component of public attention as well as of the programs of all political parties. Although the country seemed to be entering a phase of political stability, educational institutions left the impression that they were still mired in the inflexible models of the prewar era. As a result, discontent was general and demands for the modernization and rationalization of the education system were widespread and came from many different directions. From 1957 to 1959, under the conservative government of Konstantinos Karamanlis, an effort was made to map the existing situation, draft policy proposals, and to reorganize the technical and vocational school systems. ${ }^{19}$ Then, in 1964, a more progressive government under Georgios Papandreou launched an ambitious educational reform, which was abruptly discontinued by the overthrow of the government in the summer of 1965. Experts on the history of Greek education agree that, except for the interval of 1964-1965, only marginal changes occurred throughout the postwar period, and the structural problems persisted until the mid-1970s. One of these problems was the priority given to the operation of educational institutions as guarantors of political and ideological control over young people through curricular orientation, and disciplinarian sternness. $^{20}$

Within this broad picture, evening general secondary education had a subordinate role. Since early twentieth century and throughout the interwar period, evening schooling comprised two main forms. The first one was the commercial and technical training of young male and female workers. The responsibility of 
that training was chiefly undertaken by societies, chambers, and professional associations. The second form was the evening elementary schools, both public and private, which were part of a more centralized effort to combat illiteracy and achieve at least linguistic assimilation of non-Greek-speaking residents who either inhabited the northern regions added to the state territories after the Balkan Wars or who arrived in Greece as refugees after the Asia Minor catastrophe of 1922. The first evening high schools were founded in the years 1936-1937, when the right to their foundation was granted originally to the Students' Learning Association [Fititikos Ekpedeftikos Syllogos] and then the Youth Friendly Society [Filiki Eteria Neon]. The teaching staff of these schools consisted of university students and the pupils were not required to pay tuition fees. Evening high schools joined the mainstream of public education in 1949, when evening annexes of six-years schooling were established in some day public high schools. Evening high schools became autonomous and had their character as schools of working people consolidated in the period from 1959 to $1961 .^{21}$ At that time ten separate public evening high schools were established, the day schools' evening annexes were phased out, teaching staff was composed only of professional teachers, and seven-years schooling for the completion of studies was inaugurated. ${ }^{22}$

Those measures were intended to strengthen an institution that had been created in response to the increased educational requirements of disadvantaged social groups, without negating the subsidiary quality of night education. Night students actually represented only a small percentage (about three to four percent) of the overall high school population, but the increase of private night schools was an expression of a growing social demand. ${ }^{23}$ Taken together, evening high schools served a population that grew from 12,206 students in the 1954-1955 school year to 21,120 in 1962-1963. In 1954-1955 forty evening high schools were in session across the country; in 1964-1965 there were eighty-two. Unsurprisingly, the bulk of them were located in the Greater District of Athens: thirty in 1954-1955, fifty-five in 1964-1965. Evening general secondary education, thus, was a possibility largely for young people living in the wider region of the capital, although it was rife with problems of infrastructure, organization of studies, and availability of teaching staff. $^{24}$

The available evidence allows us to associate the concentration of evening high schools in the Greater District of Athens with massive internal migration to the capital during that period. A large number of young people attending evening high schools belonged to the population of young emigrants who moved to Athens alone, with their siblings, a relative, or their whole family. Social security was not a part of official agendas in postwar Greece; the poor, the working class, and the lower middle classes could not rely on social policies to build a life. Consequently, common features of the family strategies pursued by lower social groups who were aiming at survival, exiting poverty, and improving life conditions were migration, the purchase or construction of an urban house, even with the most limited means, an income dependent on the work of all or most members of the family - a practice applied also in small-scale 
family firms - and the education of children, primarily boys, which could lead them out of the precariousness of unskilled labor or to a position in the service sector. Most working pupils were a part of one or more of these strategies. $^{25}$

The bulk of pupils at evening high schools were male and female workers aged 15 to 24, an age group that in the late 1960s accounted for sixteen to seventeen percent of the economically active population. According to an early study, the highest percentage of evening pupils was fourteen to twenty years of age. ${ }^{26}$ Even though we have no accurate record of the sectors in which night pupils were employed, the available evidence allows supposing that they usually worked as support staff in large- and small-scale manufacture, trade, and food service. Many young women were typists in the private sector, while many of the young men worked in the traditional "boys' jobs" in the citythat is, as shoeshiners (loustrakia) and vendors of lottery tickets (lachiopoles) or simit ring breads (koulourtzides). ${ }^{27}$

In contrast to their urban day school counterparts, evening high schools were not single-sex schools. From the early 1960s to mid-1970s, the percentage of female pupils ranged between fourteen and seventeen percent of all enrolled persons. These numbers illustrate the gender inequality that was also recorded in the general educational level of the population and the male and female participation rates in all levels of education. Perhaps they indicate not only the strict limitation of options, which families reserved to their daughters, but, in addition, the fears of the former about the influence the night schools' environment might exercise on the girls, linked as it was in collective representations with an imagery of low school performance, delinquency, and young male workers' sexuality. On the other hand, the significance of mixed schooling should not go unnoticed; for the girls that attended and even more for those that finished evening high schools, although coeducation was not free from gender control, it could nevertheless help the emergence of a youth culture where gender roles could come under scrutiny. ${ }^{28}$

Positioned at the intersection of various inequalities, male and female pupils of evening schools experienced insecurity of wage labor, on the one hand, and the expectation that secondary education would provide them a way out, on the other. However, state interventions to standardize the operation of the evening high school linked its curriculum almost exclusively with that of the day school, without taking into account extraeducational factors that affected the lives of night pupils, such as employment and hard economic conditions. Evening high school was considered indeed an opportunity for the less privileged. The same principle that ruled the rest of educational institutions, however, dictated that within night schools, while opportunities were made available to everyone, they would eventually be effective levers of social mobility only for the most capable. The solution that the experts eventually proposed as the best way to upgrade the quality of a night school education was to introduce a seventh year of study, so that both the curriculum and teaching hours would be aligned with those of day schools. 


\section{The Creation and Action of SEMME}

The imposition of a seventh year of study triggered the first collective reactions on the part of night pupils and became the most decisive factor in the establishment of SEMME in January 1962. The association's establishment was preceded several months earlier by the formation and relentless public interventions of the Working Students' and Pupils' Coordinating Committee [Syntonistiki Epitropi Ergazomenon Spoudaston-Mathiton] that sought to have the newly enacted provision withdrawn. It was not the first time in the history of postwar Greek contentious politics that the combined attributes of working and studying were used as reference points for the assertion of young people's rights. The Working Students' Association [Syllogos Ergazomenon Fititon-Spoudaston], which had been founded in 1956 and would become an important connection between the working pupils' collective and the militant students of the Left, was the first youth club that gained official registered status after the civil war. ${ }^{29}$ It was an initiative taken by youths affiliated with EDA, which contributed considerably to the revival of the student movement, having aimed principally to mobilize the students of lower social background who had to come to grips with difficult material conditions.

The introduction of the seventh year of study was perceived by the young left-wingers of the committee as a serious discrimination against young workers and as an obstacle that would hinder their "thirst for learning and raising their intellectual and social condition." ${ }^{30}$ In one of his public speeches in 1961, Christos Reklitis, who would become the first president of SEMME, explained how the protesters conceived the effects of the measure:

Our miserable purse bears new additional financial burden to finally create our belief that the affection of the State is not shown to little breadwinners but to those "born wealthy." One year delay of our diploma means delaying our career, means at best another year of hard work and additional financial burdens, while for a large number of pupils means nothing less than abandoning their studies. $^{31}$

In the association's discourse, the working and schooling conditions that "working youth" had to endure were illustrated as one aspect of the young generation's problems, which required systematic assistance by the state and were testing the limits of social policy with regard to child and youth labor.

Of the two basic elements composing the working pupils' condition, work, and education, the second one occupied a leading position. Evening high school was outlined by SEMME as a school type that offered a solution for the education of young workers who, due to class inequalities, "were definitively condemned to ignorance." More importantly, SEMME's point was that the institution itself existed because of the demand of working pupils for access to secondary school and the acquisition of knowledge, despite the negative or indifferent attitude shown by the officials throughout the history of night 
education. ${ }^{32}$ "We, the pupils of the night" appeared as the most common definition of the SEMME's collective identity, while one of its often-repeated slogans invited fellow pupils "through the darkness of the night, to fight against the darkness of ignorance." In this discursive context, learning and education worked as instruments for the construction of a positive otherness of "night." "Night" was historically constructed as a temporal and spatial metaphor of otherness, seldom welcome by its opposite, the "day." It represented the dangers and the fears nurtured by darkness. But it was also the scene where the alienated and the marginalized of society could find shelter. ${ }^{33}$ The placement of children and youth deprived of economic and cultural capital in the educational boundaries of "night" was a clear marker of their inferiority. But within an ideological context structured by the belief in the idea of "progress" and the power of human will, it became also a challenge tackled by politicized working pupils and was used to dispute their inferior social position. Schooling and young age were their mighty weapons.

Stressing the employment status of night pupils, SEMME brought to the fore their unfavorable social position. But it was their status as pupils that ratified their inclusion into the world of youth: "The particular characteristics of a working young man [sic], and especially a working pupil," argued a columnist of the association's newspaper Mathitiki, "are his young age with enthusiasm and spontaneity, with dissimilar interests from those of the grownups who vanish under the same immiserating and exploitative labor relations." ${ }^{34}$ In different historical periods and conditions, children's labor meant their premature passage into the adult world. ${ }^{35}$ But in the postwar European context, schooling functioned as a means of prolonging the condition of youth -if not for all, certainly for many teenage workers. Through education, youth was elongated and schooling acquired priority over work as a mark of public recognition and identity, on the basis of which the collective youth subject could claim the right to participate in culture and in whatever was deemed to represent individual, social, or economic progress. Night pupils' participation in the labor market ensured their income and gave them the possibility of a professional career. But this possibility alone was no longer thought of as sufficient or satisfactory "because going to school creates greater dreams, to have a better life, more relaxed," since "every working pupil and every youngster, tending to the betterment of his life, makes efforts to obtain a ... social status and through that to satisfy the above need." ${ }^{36}$

The formation of SEMME as an association whose main task was to promote young workers' educational needs and demands was in part a response to the growing importance attributed to education as a prerequisite for equality, civilization, and democratization. Its social struggles, in particular, occurred in that context. From the second half of the 1950s onwards, a recurring, widely accepted slogan of student movements in Greece asserted the right of the poor to study. In the same vein, left-wing organizations, such as the Working Young People's of Greece Coordinating Committee [Syntonistiki Epitropi Ergazomenon Neon Elladas], stressed that the whole project of educational democratization should begin "from exactly this point: lifting the obstacles 
that block the financially weaker workers' passage to knowledge."37 Working pupils' collective action - which would prove to be probably the most longstanding movement within Greek secondary education during the first postwar decades - was part of a broader student protest movement that became more intense during the first half of the 1960s, taking advantage of the political opportunities that were generated, initially, by the electoral success of EDA in 1958 and, subsequently and more importantly, the "relentless struggle" (anendotos agonas) announced by Georgios Papandreou in 1961 and his rise to power with the Centre Union [Enosis Kentrou] in $1964 .{ }^{38}$ By 1965, SEMME's chapters had been created in almost all evening high schools of Greater Athens and a few in other towns. About twenty-three percent of the members were girls and young women, a number indicating a relatively high female participation. ${ }^{39}$ For many of the young men and women who participated in the association, this was their first contact with social movements and one of the first forms of political membership.

Similar to several other youth initiatives, SEMME was connected with the effort of EDA Youth to promote various forms of mass mobilization and trade unionism in the younger generation. According to its statute, SEMME's main purposes were to defend the interests of working pupils, make provisions for the elevation of intellectual and cultural level of its members, develop solidarity and mutual aid among them, and create the proper conditions so that both the state and society were "favorably dispose[d] towards working pupils." 40 This portrayal of the association's mission or discursive devices, such as the metaphor of the "night," were explicitly connected with the idea of political action as a process of enlightenment: "In the darkness of the night, we seek the light through learning." 41 Since both the officially provided education and the cultural opportunities offered to night pupils were regarded as ranging from incomplete to nonexistent, "from its very first steps [SEMME] tried to fill the void [left] by the lack of any kind of civilizing move in the schools." 42

Cultural activity, or "civilizing," as it was often called-an interviewee used the phrase "cultural trade unionism" - covered a significant part of the associational life. ${ }^{43}$ The same thing was happening in many mass organizations where young left-wingers were seriously involved because through the construction and spreading of a "progressive" culture, the Left sought to challenge the accusations of the anticommunist Right that the former's nature was unpatriotic and did not represent "national interests." conventional union promoting and making demands on the state, and as a cultural collectivity, which encouraged reading, writing, literary reflection, historical and scientific commentaries in the newspaper columns, dealing with art, staging plays. Perhaps the most striking characteristic in the pages of Mathitiki is how frequently one could come across texts devoted to literature, history, and science or poems composed by night pupils. These activities were part of the association's “civilizing" mission, and they had a rather normative quality 
within the conceptual space of the newspaper, as they pointed toward fields of knowledge and intellectual work deemed worthwhile or distinguished.

Yet, this set of activities, evident in the columns of Mathitiki, the association's archives and oral testimonies, did not mean just an alignment of the members with centrally planned party tactics. Furthermore, and perhaps most importantly, it represented practices of daily interaction through which those involved crafted a sense of self, gave shape to their individuality, and ascribed meaning to their relationship within a collective space.

\section{Intellectual Emancipation and Collective Life: Memories of Youth Sociality}

The contribution of oral testimonies is valuable when we try to explore the ways in which subjects negotiate private/public, personal/political relationships and how this negotiation produces consciousness that associates an individual with other individuals as well as different groups of people. Men and women who had participated in SEMME during their youth narrate this involvement primarily as a process of individual intellectual emancipation and initiation into collective life and collective expectations. ${ }^{45}$ Within their mnemonic accounts, practices such as reading or obtaining contact with literature, theater, and art are those most associated with intellectual emancipation as a critical turning point in the history of individual political awareness. $^{46}$ Any official educational opportunities might prove to be minor, incomplete, or senseless if they were not escorted by possibilities to access culture - what was conventionally considered as "high culture" - and hence improve their lives.

From the perspective of the horizon created through personal involvement with politics and collective aspirations, access to culture could be attained only by venturing on a personal, but not a lonely quest for self-development. George remembered:

Well, I had, I personally had my quests, you know? I have a picture ... We went, on a Sunday, SEMME, about twenty or thirty people, in the painting exhibition at Zappion. The national exhibitions were taking place then. We came into contact with other artists too. For example, in the organization of Kallithea Notis Mavroudis was the secretary, and each time we finished the meeting, he was taking the guitar and played, let's say Segovia, for us. In the Fifth [Evening High School] was Linos Kokotos. And then we staged that awesome play of $A$ Child Counts the Stars ... [In SEMME] we were working in companies of friends. ${ }^{47}$

It was a quest that contributed to the development of personality and, therefore, allowed the subjects to imagine alternative possibilities for their future. Mary was one of the actresses in that play mentioned by George. She remarks,

We acquired a quality in whatever we did. I mean, look at me; I was fifteen when I got involved in theatre ... There was a quality, I wouldn't go with a girlfriend to 
play cards or, I don't know, do other things ... Or read fancy magazines ... I mean, I moved to Athens when I was 12 years old and my elder brother already had a huge library ... And me, since I was very young, I was reading, reading literature ... I mean, when I was fifteen-sixteen, I had already read the complete works of Jules Vernes, I mean whatever there was.

Creativity that allows subjects to circumvent the restrictions raised by class position is evident not only in today's accounts of youthful life but also in the way in which SEMME sketched, at that time, night pupils' image into its public discourse. The artistic columns in Mathitiki were persistently looking for and featuring working pupils' endeavors and successes in music, poetry, and painting. "They deserve every praise" was written, for example, in a 1967 issue presenting the painting exhibition by seven pupils who attended the Evening School of Peristeri, the largest suburb in the western working-class fringes of the capital. According to the columnist, the seven honored young painters represented all night pupils who overcame "the difficulties of working and studying, [and] often find time to deal creatively with intellectual and artistic issues that establish them before the eyes of society." 48 Artistic expression had an interrupting quality; it could create a break in the rhythms of daily work, deconstruct the widely admitted sociological representation of night pupils as second-class citizens, and perform the act of "breaking down the time-honored barrier separating those who carried out useful labor from those who pondered aesthetics." 49

What made intellectual emancipation possible? There is a general historiographical consensus on the cultural changes that mostly affected postwar youth in a large part of the world: expanding educational provision, broadening of access to schooling, urbanization, proliferation of cultural products in both commercial and noncommercial form, increased income of the respective age groups, adolescents and youngsters. Those were major changes that might render existing power relations more vulnerable to challenge and generate feelings of hope regarding future prospects. Still, they did not manifest themselves in uniform ways, in terms of geographical location, social groups, timing, and rhythm of the influence they exerted.

In postwar Greece, to be more specific, income inequalities, uncertainty of employment, and poverty - until at least the late 1970s-directly affected how boys and girls of the lower classes managed their daily survival and what patterns of consumption behavior they showed. ${ }^{50}$ For them, cultural transformation was primarily related to the fact that for the first time young people coming from a working-class, lower peasantry, or urban poor backgrounds could have access to higher education and, therefore, to the riches of civilization. Usually, they migrated from the countryside to Athens, leaving the village behind in order to find new paths that opened up their personal and social lives. In this context, school was a test area of individual willpower. This major shift, however, was not experienced by those young people as an offer from organized society and the state, but rather as a personal goal and achievement, which took a lot of hard work. 
The memories of SEMME members bear the traces of this cultural transformation as the narrators recount their ability to plan their own lives based on their fresh contact with politics, education, and culture. Mary, for instance, did not have an image of her parents as politically involved, but she did have such an image when it came to her elder siblings. "It was the circumstances that brought us [the younger generation of the family] to different points," she reflects, "because, as you pursue life, and you search and you read, there comes a moment that you become aware of certain things whether you like it or not. You become aware."

In these narrations, social, cultural, and personal transformations do not take place in explosive action scenes, but in instances where everyday actions, such as reading, are recognized as markers of creativity. "All that was a skein that you unrolled little by little," Mary remembered, "as you search and you read, there comes a moment that you become aware." In the oral testimonies that concern us here, reading activity becomes a politicized practice, as the subjects convert it into a means to make something for themselves, an art to handle and enjoy the products of culture, a method to benefit from forces hardly familiar to the precedent generations. 51

Comparing her own experiences with those of her parents, Mary remembers that her mother had

... always wanted us to read history to her. And she used to say: "Me, my mother she didn't get me an education, because I was the first child of a six-member family," whose father passed away while the last child was still in my grandmother's womb ... And, so, they gave my mother to get married, the very first child, they gave it away to have a mouth less to feed, actually, to be done with that one. And she used to say, though she was a very intelligent person, she always said this: "Me, my mommy she didn't get me an education." That was it ... she experienced this ... and this is what she liked of us, that we loved learning, we were reading books.

Although illiteracy was a practical and symbolic barrier for the generations who had come into the world in the first half of the twentieth century, their children's literacy not only meant the lifting of this obstacle, but also functioned as a metonymy for the subjects' creativity per se, for their ability to imagine, to interpret, and to invent through text reading. Reading activity emerges, thus, as one of the signifying practices that shaped a sense of self and offered points of connection between individual and collective trajectories. "I began having conversations." George told me. "I began reading, they were giving me books, Gorky's The Mother, How the Steel Was Tempered ... and I entered some circles of that sort."

Creativity hidden in reading was one of the paths leading to intellectual emancipation. Although the latter emerges as indispensable to greater freedom for the individual and therefore encourages a sense of distance from earlier family and personal experiences, nevertheless education in and of itself 
does not entail a complete estrangement from the past. Memory bears witness to the suffering, and sometimes the mental pain, caused by inequalities and compulsions experienced directly or indirectly, either by the narrators themselves or by their mothers, fathers, brothers, sisters, and other family members. Some of these inequalities and compulsions were related to gender, class, age, politics, and geography. In the oral testimonies of SEMME members, discontinuities with the past in terms of experiences are interspersed with continuities represented by shared moral or political values. The interviewees' own trajectories, in which strong political commitment and a search for learning played a central role, seem to compensate for the injustices of the past, such as the exclusion of women from the educational system or the fear and frustration of those defeated in the civil war.

As already mentioned, making use of educational opportunities and putting an end to past inequalities was not a solitary effort. On the contrary, it was an effort interwoven with spaces that were created within the context of associational life as well as in other sorts of communicative action. Memory reconstructs the space of free youth activity as an environment that, taken as a whole, shaped a grid of loosely or tightly knotted relations. Youth is remembered, in large part, as the recollection of life in these common spaces, which the narrators shared with others. "You should see pictures of excursions, a whole bunch of them," noted Mary, "and not far away, we went to nearby destinations that we could reach by bus. There was neither car nor anything ... There was always this collectivity of the company of friends ... and good music."

Young workers' lives in SEMME tended to trespass the boundaries between the public and the private. In the oral accounts of individual lives, we can sense a distinct juvenile political and cultural identity, which was formed through the transition to forms of "communication and appropriation of new times and spaces" both cultural activities or different locations of the citysites of collective protest, of friendly gathering, of leisure wandering, of the Sunday excursion. ${ }^{52}$

Theater is perhaps the most eloquent example of the passage into collective life. Both in oral interviews and in SEMME's archival records, we find persistently repeated descriptions, comments, and snapshots of the staging of the play A Child Counts the Stars in the summer of 1965. The night pupils' theatrical group had made its first steps in spring 1962, with small sketches that were presented during SEMME's excursions. Within three years the group had thrived and in spring 1965, having done a lot of personal work and fundraising, its members were in the position to adapt Menelaos Lountemis' novel, to build the sets and rehearse for the opening night, sometimes in the association's headquarters, sometimes in a courtyard and, eventually, on the stage of an actual theater (Veakis Theater), which was leased for the show. The book had been selected because, according to the SEMME record, it reflected the life of the child that migrated from the countryside to the city and was forced to work for a living, while it presented both the old convictions about education and the modern trends. 
But what was more important, "a pupil directed the play, a pupil wrote the scenario, a pupil composed the music, a pupil provided all the technical means (lights, telephone machines, etc.), all hand-made." Five young men and boys formed the group that started the whole enterprise: one employed in a butcher's shop, one in a printing shop, one in a confectionary workshop, a construction worker and a peddler. The show was a success, and, in the next couple of months, the "troupe" toured in several towns of the Greek province. When SEMME looked back upon the members' theatrical activity, it stressed that

... a theatrical group consisting of working pupils is not the norm, at least in our country. The venture was big. The difficulties, enormous. The shortcomings, unthinkable. Even so, the venture was undertaken. And it succeeded. Because it was attempted by children burning with the flame of creation. And because it was supported by children thirsty for something good, true, of their own. ${ }^{53}$

Today's accounts maintain the same admiration toward the accomplishments of that young people's troupe. Like reading, theater acquires the quality of a signifying practice within which one recognizes agency and creativity. Night pupils' theatrical activity can be regarded as one of the forms of distinct cultural practice taken by the collective, which help us understand the relationship between art and social energy in different historical periods. Theater, in particular, is manifestly the product of collective intentions and addresses its audience and its artists as a collectivity: The model is "the crowd that gathers together in a public play space ... [There is] no attempt to isolate and awaken the sensibilities of each individual member of the audience." Theater "depends upon a felt community." 54 The central position that theatrical production took when interviewees recounted SEMME's activities, and the variety of emotional expressions enhanced by this recollection, suggests that the notion of "felt community" captures with sufficient precision the manner in which memory-at least the mnemonic narratives I can point to-has conceptualized the experience of participation and collective action through SEMME:

We were kids, we laughed, we did our thing, we gathered ... but we also made jokes throughout [the rehearsal] ... It was a nice experience, I can say, very nice experience ...

D.L.: Why did you do it?

Because, first of all, we were having a good time. This is it. Quite simply, we had a very good time. And all this was creative, but at the same time there was this communication. I think that all that matters was communication. (Mary)

\section{Conclusions}

Notions of "communication" and "creativity" determine to a great extent the content of sociality that was formed through the collective action of SEMME 
and, more generally, of the political identity of young people who were affiliated with the Left and social movements of the 1960s. By encouraging collective life, the activities of SEMME pointed to the political importance of democracy and social equality. However, in the association's public discourse, as delivered by the newspaper Mathitiki and archival records, the values of democracy and equality coexisted with didacticism and the will for controlling members' behavior. This is not news, of course, as these elements had been long known in the history of left-wing movements. Nevertheless, this inherent contradiction does not seem to trouble the available retrospections of SEMME's nature and activities. In these recollections, individual political membership is identified with, on the one hand, the search for and the possibility of intellectual emancipation and, on the other, the collective life and the felt community. ${ }^{55}$ Political action may be oriented toward conflict with the government and the state, yet this orientation was not considered a prerequisite for an action to be political. In these mnemonic narratives, we watch unfold reflections on the prejunta sixties, which designate the period as a time of preparation for the great battle that would soon follow, the battle against dictatorship. Chiefly, however, this epoch clearly emerges as the time of creation of cultural stances and collective values that would support individual social mobility and prove to be an anchor, not only for the intense political moments that would follow, but also for less activist, everyday moments in the narrators' lives.

This conceptualization of prejunta political action is, as we have seen, noticeably associated with the forms and content of SEMME's action. However, the emphasis given by the narrators on cultural practices within the associational life and the importance of these practices for the self-awareness of the subjects indicate the ways through which collective action offered patterns of knowledge, of relationships, and acts to these young people. Embracing these patterns, they could tackle the dramatic changes and pressures exercised by the economic, political, and ideological environment of their time. The importance of SEMME as a distinct working-class youth collectivity had mostly to do with the possibilities it created for its members to meet needs beyond those that arose in the workplace. It did so by stressing the importance of education and access to culture as key components, more essential than work, for the personality, the identity, and the individual or collective expectations of young people.

That literacy and educational provision constitute a positive framework for political action and public recognition is not new. Yet, there is novelty in the close correlation between education and young age, the rights arising from it, and the widening of the scope of these rights to young men and women who had already been included in the labor market. For these reasons, the historical study of an organization like SEMME can contribute to the exploration of postwar social transformation in general and to our understanding of how this transformation was experienced, perceived, and orientated in the daily lives of adolescents and young men and women coming from the lower social strata in particular. Adolescents and young people found themselves facing the improvement of their living conditions as a tangible possibility, unknown 
to preceding generations. It was a possibility for which education had been a prerequisite and constituted part of more or less structured visions of what civilized everyday life, politics, and society might mean.

\section{NOTES}

1. Research for this article was conducted as part of the research project "Forms of public sociality in 20th century urban Greece: Associations, networks of social intervention and collective subjectivities" (Co-ordinator: Efi Avdela, University of Crete) under "Thalis: 10.74.11.03. Reinforcement of Interdisciplinary and Interinstitutional Research and Innovation" for priority axe 10, NSRF. I would like to thank the members of the Thalis project research collectivity and especially Efi Avdela for creating one of the most fertile and democratic environments one could encounter in the academic life. I am also indebted to my peer reviewers for their important comments. I would like to express my deep sense of thanks to ILWCH editor Michael Merrill for his suggestions and support.

2. Geoff Eley, "Nations, Publics, and Political Cultures: Placing Habermas in the Nineteenth Century," in Culture/Power/History. A Reader in Contemporary Social Theory, ed. Nicholas B. Dirks, Geoff Eley, and Sherry Ortner (Princeton, 1994), 297-335.

3. SEMME was aimed at pupils who attended general non-vocational high schools held in the evening. In 1960s' Greece, pupils of vocational and technical schools were represented in distinct associations. General evening high schools (Nychterina Gymnasia/Lykia) offered a traditional secondary school-type curriculum and allowed working people to gain access to higher education by successfully completing the required years of attendance and number of exams. They resembled, in that sense, the German Abendgymnasium. In the relevant literature, the terms "evening school" and "night school," which are used interchangeably in this paper, usually refer to adult education. This is not the case with the evening high schools I'm studying here, which could be attended generally by pupils who had finished elementary school and were over 14 years old. For further information about relative terminology, see Peter Jarvis, International Dictionary of Adult and Continuing Education (London, 2002).

4. I use here the following surveys of Greek history written in English: David Close, Greece Since 1945 (London, 2002), 16-113; Thomas W. Gallant, Modern Greece (London, 2001), 178-95; William H. McNeil, The Metamorphosis of Greece since World War II (Oxford, 1978), 206-46.

5. Ilias Nikolakopoulos, I kachektiki dimokratia. Komata kai ekloges, 1946-1967 [The Feeble Democracy. Parties and Elections, 1946-1967] (Athina, 2000); Nikos Alivizatos, Les institutions politiques de la Grèce à travers les crises 1922-1974 (Paris, 1979).

6. The relative bibliography is huge. References used here are Axel Schildt and Detlef Siegfried, eds., Anamesa ston Marx kai stin Coca-Cola. Neaniki kultura kai kinoniki allagi, 1960-1980 [Between Marx and Coca-Cola] (Athina, 2006); Giovanni Levi and Jean-Claude Schmitt, eds., A History of Young People in the West (Cambridge, 1997); Jean-François Sirinelli, Les Baby-Boomers. Une génération 1945-1969 (Paris, 2003); Richard Ivan Jobs, Riding the New Wave. Youth and Rejuvenation of France after the Second World War (Stanford, 2007). For the Greek case: Efi Avdela, "Nei en kindyno." Epitirisi, anamorfosi ke dikeosyni anilikon meta ton polemo ["Young People in Danger." Surveillance, Rehabilitation and Juvenile Justice after the War] (Athina, 2013); Nikolaos Papadogiannis, Militant Around the Clock? Left-Wing Youth Politics, Leisure, and Sexuality in Post-Dictatorship Greece, 19741981 (New York and Oxford, 2015); Kostis Kornetis, Children of the Dictatorship. Student Resistance, Cultural Politics, and the "Long 1960s" in Greece (New York and Oxford, 2013); Vaggelis Karamanolakis, Evi Olympitou and Ioanna Papathanassiou, eds., I elliniki neolea ston 20o eona. Politikes diadromes, kinonikes praktikes kai politistikes ekfrasis [Greek Youth in the $20^{\text {th }}$ Century. Political Trajectories, Social Practices and Cultural Expressions] (Athina, 2010); Ioanna Papathanassiou, I neolea Lambraki ti dekaetia tou 1960. Archiakes tekmiriosis ke aftoviographikes katathesis [The Lambrakis Youth in the 1960s. Archival Documentation and Autobiographical Testimonies] (Athina, 2008); Katerina Saint Martin, Lambrakides. Istoria mias genias [Lambrakides. A Generation's History] (Athina, 1983). 
7. In Greece, massive student demonstrations from 1951 to 1957 supported the struggle of the Cypriot people against British colonial rule. It has been argued that in the context of those youth demonstrations, dominant notions of patriotism, which legitimized political post-civilwar authoritarianism, were drastically undermined; Nikos Serdedakis, "I diadromi tou fititikou kinimatos sti metemfiliaki Ellada" ["The Trajectory of the Student Movement in Post-Civil War Greece"], in Karamanolakis, Olympitou, and Papathanassiou, I elliniki neolea ston 20o eona, 160-82. On the Cypriot question and the emergence of the Independent Republic of Cyprus (1960), Evanthis Hatzivassiliou, The Cyprus Question, 1878-1960. The Constitutional Aspect (Minneapolis, 2002); Ioannis D. Stefanidis, Isle of Discord: Nationalism, Imperialism and the Making of the Cyprus Problem (London and New York, 1999). Until 1967, the EDA (19511974) was the legal party of the Greek communist Left and its political allies. In 1958 it gathered twenty-four percent of the vote and became the main opposition party, alarming thus the political system.

8. George Voiklis (April 16, 2014) and Mary Toliou (November 19, 2014) interviews. Both interviewed by Dimitra Lampropoulou. Hereafter references to these interviews only by the narrators' first names: George and Mary.

9. On the antijunta student movement, see Kornetis, Children of the Dictatorship.

10. Archival material about SEMME in Archia Sygxronis Kinonikis Istorias, Archio EDA, Archia Neoleas [Contemporary Social History Archives, EDA Archive, Youth Archives], hereafter ASKI, Archio EDA, Archia Neoleas; Eteria Meletis tis Istorias tis Aristeris Neoleas [Society for the Study of the History of Left-wing Youth], hereafter EMIAN. Interviews by Evaggelia Viazi-Tsilaga (February 20, 2014), George Charalambakis (February 8, 2014), Christos Reklitis (February 10, 2004), Christos Tolios (May 7, 2014), Mary Toliou and Socratis Bembezas (November 19, 2014); all conducted by Dimitra Lampropoulou.

11. ASKI, Archio EDA, Archia Neoleas, b.es 282, 304, and 305.

12. Mark Mazower, Skotini ipiros. O evropaikos ikostos eonas, [Dark Continent. European Twentieth Century] (Athina, 1997), 329-440. Postwar years are often designated as an era of "social and cultural revolution." See Eric Hobsbawm, I epochi ton akron. O syntomos ikostos eonas 1914-1991 [The Age of Extremes. The Short Twentieth Century 1914-1991] (Athina, 1997), 329-440. Tony Judt has argued that conceiving that period as an era of transcendence by the contemporaries was a particular characteristic of the "sixties." The generation of the sixties saw the world as "new and young," in Tony Judt, Postwar. A History of Europe Since 1945 (New York, 2005), 390-95.

13. Mazower, Skotini ipiros, 299.

14. Charles Dorn and Kristen Ghodsee, "The Cold War Politicization of Literacy: Communism, UNESCO, and the World Bank," Diplomatic History 36 (2012): 373-98.

15. Judt, Postwar, 391.

16. On "ordinary people's" emotional and intellectual stances toward questions of social justice after World War Two, Sally Alexander, "Memory-Talk: London Childhoods," in Memory: History, Theories, Debates, ed. Susannah Radstone and Bill Schwartz (New York, 2010), 235-45. More specifically on educational matters, Brian Jackson and Dennis Marsden, Education and the Working Class (Harmondworth, 1966). On the growing numbers of students, secondary schools, and universities, Judt, Postwar, 390-95.

17. The 1961 census counted $1,220,000$ declared "illiterate" people out of $6,888,100$ whose age was more than ten years; 970,000 were female. In 1971, 1,015,180 were recorded as officially "illiterate" of whom 798,240 were female; National Statistical Service of Greece, Censuses of the years 1961 and 1971. See also Athina Sipitanou, O analfavitismos stin Ellada: I diachronikotita ke I metallages tu provlimatos [Illiteracy in Greece: The Diachronic Dimension and the Mutations of the Problem] (Thessaloniki, 1998). The basic postwar legislation on the combat against illiteracy was Statutory Instrument 3094/1954 on the illiteracy alleviation, Government Gazette 252/A/October 12, 1954.

18. Maria Eliou, "Those Whom Reform Forgot," Comparative Education Review 22 (1978): 60-70.

19. The task of mapping the existing situation was assigned to the "Education Committee" which was established by Karamanlis administration in summer 1957; Alexis Dimaras, Istoria tis neoellinikis ekpedefsis. To "anakoptomeno alma." Tasis kai antistasis stin elliniki ekpedefsi 18332000 [History of Modern Greek Education. The "Intercepted Leap." Trends and Resistances in Greek Education 1833-2000] (Athina, 2013), 224-29. Rationalization of the system of technical and vocational education was the aim of Statutory Instrument 3971/1959 "on technical and 
vocational education, organization of secondary education and administration of education," Government Gazette 187/A/September 9, 1959.

20. Dimaras, Istoria tis neoellinikis ekpedefsis, 193-247; Pantelis Kyprianos, Syngritiki istoria tis ellinikis ekpedefsis [Comparative History of Greek Education] (Athina, 2004), 23583; Sifis Bouzakis, Ekpedeftikes metarrythmisis stin Ellada. V.II: Metarrythmistikes prospathies 1959, 1964, 1976/77, 1985, 1997/98 [Educational Reforms in Greece. V. II: Reformation Attempts of 1959, 1964, 1976/77, 1985, 1997/98] (Athina, 2002), 81-256; Anna Frangoudakis, "The Impasse of Educational Reform in Greece: An Introduction," Journal of the Hellenic Diaspora 8 (1981): 7-18.

21. Statutory Instrument 3971/1959 "on technical and vocational education"; Royal Decree 617/1961 "on definition of evening high schools' curriculum, alignment of their grades to those of day high schools and general adjustment of their operation," Government Gazette 149/A/September 9, 1961.

22. Sociological studies of evening education in Greece are Pantelis N. Galitis, Sto kinigi tou chronou. Esperini ekpedefsi kai kinonikos apoklismos [Chasing Time. Evening Education and Social Exclusion] (Thessaloniki, 2011) and Chariklia Rizou, "Esperini ekpedefsi stin Ellada: istoriki ekseliksi kai aposafinisi tou rolou tou esperinou gymnasiou sti sygchroni pragmatikotita" [Evening Education in Greece: Historical Development and Explanation of the Role of Evening High School in Today's reality] (Ph.D. diss., University of Crete, 2004).

23. Censuses 1961 and 1971; Galitis, Sto kinigi tou chronou. Increasing demand of evening secondary education was also recorded in the conclusions of the "Education Committee" published in 1958, a broad description of the conclusions in Rizou, "Esperini ekpedfsi stin Ellada," 201-205.

24. Shortages of teaching staff and classrooms were permanent problems of evening high schools. Overcrowding, courses taught in inadequate spaces, such as warehouses, and forced holiday one day per week were some of the listed problems of night high schools; reports and pictures in Mathitiki 7 (November 27, 1963), 16 (November 29, 1965), 19 (October 27, 1966).

25. Versions of these familial strategies are recorded in all the interviews cited in note 11. Educational incentives of internal migration in postwar Greece have been recorded since the early studies on the issue. A detailed review in Paraskevi Kapoli, "I esoteriki metanastefsi stin Athina (1949-1967)" [Internal Migration to Athens (1949-1967)] (Ph.D. diss., University of Athens, 2013) 210-228. On internal migration as a central experience in the lives of many young men who worked in the developing constructing sector in postwar Athens, a large part of whom attended night schools, and on housing practices, see Dimitra Lampropoulou, Ikodomi. I anthropi pou echtisan tin Athina, 1950-1967 [Construction Workers. The People who Built Athens, 1950-1967] (Athina, 2009), 35-77, 135-70.

26. Rizou, "Esperini ekpedefsi stin Ellada," 200.

27. "To 6oro ke I mathites tis nychtas" [6-hour Working Day and the Pupils of the Night], Mathitiki 16 (1965): 3; Giannis Theodorakis, "Me tous mathites tis nychtas" [With the Pupils of the Night], Dromi tis irinis 47 (1961): 13-15. Information also drawn by the interviews cited in note 9 .

28. According to Rebecca Rogers, for girls and boys the most significant educational change of the postwar world was coeducation in elementary and secondary schools; Rebecca Rogers, "Learning to be Good Girls and Women. Education, Training and Schools," in The Routledge History of Women in Europe Since 1700, ed. Deborah Simonton (Abingdon, 2006), 93-133. In Mary Toliou's and Dounia Kousidou's (December 8, 2013, interview conducted by D. Lampropoulou) narratives, mixed schooling, and the mixed associational sociality of SEMME are presented to be encompassing gendered hierarchies but, at the same time, to support a message of potential independence and equality for women.

29. Papathanassiou, I neolea Lambraki, 54.

30. ASKI, Archio EDA, Archia Neoleas, b. 305: SEENE (Working Youth Coordinating Committee), "Cheretismos" [Public address] (1962-4); "Katastasis-Deltion ton energion tis S. E. SEMME" [List-Newsletter of SEMME C.C.] (September 9-December 11, 1963), "Ta provlimata pou antimetopizi o SEMME" [The problems SEMME is facing] (1963).

31. Syntonistiki Epitropi Ergazomenon Mathiton-Spoudaston, "7o etos," EMIAN, Syllogi M. Papoulia kai S. Ventouratou.

32. "Ta 30 chronia ton Nychterinon Gymnasion" [Thirty Years of Evening High Schools], Mathitiki 23 (1967): 4. 
33. Bryan D. Palmer, Cultures of Darkness: Night Travels in the Histories of Transgression [From Medieval to Modern] (New York, 2000), 1-20. Also available in a Greek translation as Kultures tis nychtas. Nychterines periegesis stis istories paravasis apo to meseona mechri simera, (Athina, 2006), 31-41.

34. Tassos Papadopoulos, "I synthikes ergasias ton ergazomenon mathiton" [Working Conditions of Working Pupils], Mathitiki 19 (1966): 3.

35. Philippe Ariès, Eones pedikis ilikias [L'enfant et la vie familial] (Athina, 1990), 230-53.

36. T. Papadopoulos, "Epaggelmatikos prosanatolismos tou ergazomenou mathiti" ["Working Pupil's Vocational Orientation"], Mathitiki 23 (1967): 3.

37. Syntonistiki Epitropi Ergazomenon Neon Elladas, "Public address" (1962-1964), EDA Archive, b. 304, ASKI.

38. After the 1961 general elections, G. Papandreou charged electoral fraud and demanded that the elections be declared void, announcing thus his "relentless struggle" to ensure free and fair elections. Widespread allegations of tampering and corruption and the intimidation of voters by paramilitary groups and the security forces, especially in areas with left-wing sympathies, had caused popular indignation and gave the opportunity for a mass anti-Right-wing movement. In the February 1964 elections, G. Papandreou and his recently formed Centre Union (liberals and a minority of moderate center-left-wingers) gained a majority that allowed them to come and stay to power until mid-1965. It was the first non-Right-wing government since 1953, which attempted to reform some socially sensitive sectors, such as educational institutions, and succeeded to soften anticommunist legislation. With the decisive intervention of the monarch, Papandreou's government was overthrown in the summer of 1965. In the meantime, the governmental change had boosted wide expectations for democratic reforms. For an overview, see Gallant, Modern Greece, 194-96; Close, Greece since 1945, 83113. On the dynamics of students' movement, Serntedakis, "I diadromi tou fititikou kinimatos"; Christoforos Vernardakis and Giannis Mavris, Komata ke kinonikes symmachies stin prodiktatoriki Ellada. I proypothesis tis metapolitefsis [Parties and Social Coalitions in Pre-Dictatorship Greece. The Preconditions of Post-Dictatorship Period] (Athens, 1991), 136-66; Papathanassiou, I Neolea Lambraki, 31-109.

39. Thanassis Kalafatis, "To kinima ton mathiton tis nychtas 1962-1967 kai I symvoli tou Christou Rekliti" ["Night Pupils' Movement 1962-1967 and Christos Reklitis' Contribution"] in EMIAN, Christos Reklitis 1937-2014 (Athens, 2014), 9-31.

40. "Katastatiko SEMME, 1962" [SEMME Statute, 1962], ASKI Archio EDA, Archia Neoleas, b. 305.

41. Dromi tis irinis 47 (1961): 13.

42. "Mathitiki evdomada," ["Pupils' Week," address to the inauguration of Pupils' Week], 1963-1967; "Syndikalismos kai mathites tis Nychtas. O syndikalismos sta Nychterina Gymnasia" [Trade unionism and pupils of the night. Trade unionism in Evening High Schools], review composed by the trade-union committee of SEMME, 1962-1967; "Ekpolitismos" [Civilizing process], notes for a SEMME's brief; all three in ASKI, Archio EDA, b. 305. See also, Theodorakis, "With the pupils of the night."

43. Dounia Kousidou interview. In Greek, the word "politismos" is used for both "culture" and "civilization." Among other definitions, "politismos" means (a) the totality of physical, intellectual, technical achievements and performance, which is the result of human creative forces and abilities and is expressed historically on society's types and forms of organization and action as well as on the creation of (material and spiritual) values; (b) the totality of human intellectual and artistic achievements and performance (arts, science, institutions, law, religion, customs, etc.), culture [kultura]; (c) state, way of life, and behavior achieved through learning and education, entry "politismos" in Aristotelio Panepistimio Thessalonikis-Instituto Neoellinikon Spudon, Lexiko tis kinis neoellinikis [Aristotle University of Thessaloniki-Institute of Modern Greek Studies, Dictionary of Modern Greek Language] (Thessaloniki, 1998).

44. Papadogiannis, Militant Around the Clock, 27.

45. In different tones, intellectual emancipation as one of the constituent parts of a new political culture for the "1968 generation" is highlighted in Passerini, Autobiography of a Generation: Italy, 1968 (Middleton, 1996), 22-36.

46. By "intellectual emancipation" I mean the subjective space of experience, which is chronicled as a process that encompasses in its start making use of any educational opportunity 
and rupturing established cultural constraints, directing, thus, a person to new ways of thought and action.

47. Notis Mavroudis and Linos Kokotos became renowned musicians; A Child Counts the Stars is a novel written by the author Menelaos Lountemis, published in 1956.

48. Mathitiki 23 (1967): 2.

49. Jacques Rancière, "Good Times or Pleasures at the Barriers," in Voices of the People. The Social Life of "La Sociale" at the End of the Second Empire, ed. Adrian Rifkin and Roger Thomas (London, 1988), 50; quoted in Donald Reid, "Introduction" to Jacques Rancière, The Nights of Labor: The Workers' Dream in Nineteenth Century France (Philadelpia, 1989), xvxxxvii.

50. Hard conditions are recorded in all oral interviews I have conducted so far. On the misery poor working-class families had to face: Avdela, Nei en kindyno, 275-303. On income inequalities and consumption habits: Vassilis Karapostolis, I katanalotiki symperifora stin elliniki kinonia 1960-1975 [Consumption Behavior in Greek Society 1960-1975] (Athina, 1984).

51. Practices of everyday culture, among which reading is a central case, are analyzed by Michel De Certeau in L' invention du quotidian. Arts de faire (Paris, 1990). I use here the Greek translation: Epinoontas tin kathimerini praktiki. I polytropi techni tou prattein (Athina, 2010), 369-89.

52. Passerini, Autobiography of a Generation, 98.

53. Information and citations from untitled manuscripts about the activities of the theatrical group; "Ta provlimata pou antimetopizi o SEMME" [The problems SEMME is facing], handwritten draft; both in ASKI, Archio EDA, b. 305. Also, "Ekpolitismos. To mathitiko theatro" [Civilizing Process. The Pupils' Theatre], Mathitiki 16 (1965): 2.

54. Stephen Greenblatt, "The Circulation of Social Energy," in Dirks, Eley and Ortner, Culture/Power/History, 504-19.

55. In this perspective, it would be interesting to study not only the breaks and discontinuities but also the continuities between prejunta, antijunta, and postjunta political activity for which it has been aptly written that young left-wingers, regardless their specific party affiliation, perceived their political activity as a strong emotional experience. Papadogiannis, Militant Around the Clock, 6. 